\title{
Asymptomatic multinodular splenoma (splenic hamartoma) in a child with sickle cell anemia
}

This article was published in the following Dove Press journal:

International Medical Case Reports Journal

12 July 2017

Number of times this article has been viewed

\author{
Narcisse Elenga' \\ Sylvain Labbé ${ }^{2}$ \\ Nicolas Leduc ${ }^{2}$ \\ Anicet Sika' \\ Emma Cuadro' \\ Laurence Long' \\ Falucar Njuieyon' \\ Rémi Kom-Tchameni' \\ Thierry Basset' \\ 'Department of Pediatrics and \\ Pediatric Surgery, Pediatric Medicine \\ and Surgery, ${ }^{2}$ Pathological Anatomy \\ Department, Cayenne Hospital, \\ Cayenne Cedex, French Guiana
}

Correspondence: Narcisse Elenga Department of Pediatrics and Pediatric Surgery, Pediatric Medicine and Surgery, Cayenne Hospital, Rue des Flamboyants, BP 6006, 97306 Cayenne Cedex,

French Guiana

Tel +594 694978048

Email elengafr@yahoo.fr

\begin{abstract}
Splenoma is a rare and benign malformation usually fortuitously diagnosed during imaging, surgery or, unfortunately, at autopsy. Although splenoma was first described in 1861, its association with hematological pathology is a very unusual condition in children. We report the case of an asymptomatic splenoma in an 8-year-old boy with sickle cell anemia, whose diagnosis was confirmed after conventional splenectomy.
\end{abstract}

Keywords: multinodular splenoma, child, sickle cell anemia, conventional splenectomy

\section{Introduction}

Splenic hamartoma - or splenoma - is a rare and benign malformation usually fortuitously diagnosed during imaging, surgery or even autopsy. ${ }^{1}$ It originates from an aberrant mixture of normal splenic tissues. Symptoms may occur from mass effect of the growing hamartoma over the surrounding organs. Although splenoma was first described in 1861, its association with hematological pathology is a very unusual condition in children. In this article, we report the case of an asymptomatic splenoma in an 8-year-old boy with sickle cell anemia (SCA), whose diagnosis was confirmed after conventional splenectomy.

\section{Case presentation}

Multiple splenic nodules were found during the routine ultrasonography checkup of an 8-year-old boy affected with homozygous SCA.

He had a medical history of multiple emergency admittances for vaso-occlusive crisis. He underwent sequential transfusions after one episode of acute splenic sequestration, another after one infection by parvovirus-B19 and, lastly, after one episode of pulmonary Amazonian toxoplasmosis. His height, weight and psychomotor development were normal despite a base hemoglobin level of $7-8 \mathrm{~g} / \mathrm{dL}$. He was admitted for planned splenectomy, 1 month after initial imaging diagnosis, because of the persisting and possibly malignant splenic nodules. Physical examination was normal and showed neither splenomegaly nor hepatomegaly. Routine blood tests showed red blood cells (RBC) count as $2.03 \times 10^{12} / \mathrm{L}$, white blood cell (WBC) count as $17.70 \times 10^{9} / \mathrm{L}$ and platelet count as $294 \times 10^{9} / \mathrm{L}$, with normal hemostasis tests. Liver enzyme levels were normal, as were total bilirubin, serum creatinine and carcinoembryonic antigen levels. Ultrasound imaging followed by tomodensitometry showed both splenomegaly and three hyperechoic splenic masses, whose respective diameters were 3, 2.5 and $2 \mathrm{~cm}$. These images had an irregular shape, poorly defined borders and a rough capsule. 
Possible differential diagnosis included angiosarcoma, primary splenic lymphoma and multiple splenic metastases. The child received a preoperative exchange transfusion. Percentage of Hemoglobin-S decreased from $98 \%$ to $25 \%$. Preoperative hemoglobin level was $9 \mathrm{~g} / \mathrm{dL}$.

A conventional splenectomy was performed in order to provide histopathological diagnosis. The patient was set on the surgery table in a right semilateral decubitus position, with the left arm tucked above his head. A transversal incision measuring $7.5 \mathrm{~cm}$ was performed in the upper left quadrant of the abdomen and three ports were used. The splenic artery at the tail of pancreas was doubly ligated with absorbable suture. After mobilization of the spleen, the splenic vein found at the hilus lienis was finally ligated.

Duration of surgery was 50 minutes, and the estimated intraoperative blood loss was equal to zero. The postoperative course was uneventful, and the patient was discharged 7 days after surgery.

The resected organ weighed $265 \mathrm{~g}$ and measured $9.0 \mathrm{~cm} \times 9.0 \mathrm{~cm} \times 3.5 \mathrm{~cm}$ (Figure 1). Three splenic nodules were found, with respective diameters of 3.5, 2.5 and $3 \mathrm{~cm}$. Within these nodules, the red pulp tissue was disorganized, and no interspersed white pulp areas were found. Neither Gamna-Gandy bodies nor infarcts were identified. Microscopically, lesions had a typical architecture, with a capillary proliferation. Immunochemistry was positive for cluster of differentiation (CD)31, CD8 (Figure 2) and CD34 (Figure 3), but negative for human herpesvirus 8 (HHV8) (Figure 4). All these findings supported the diagnosis and confirmed the initial suspicion of splenic hamartoma. $^{2}$

\section{Consent}

The parents of the patient gave their written informed consent for the case report to be published.

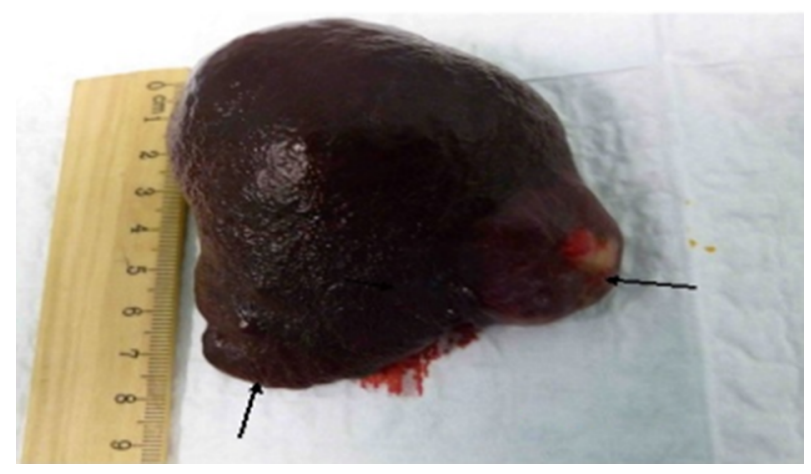

Figure I Multiple splenic nodules.
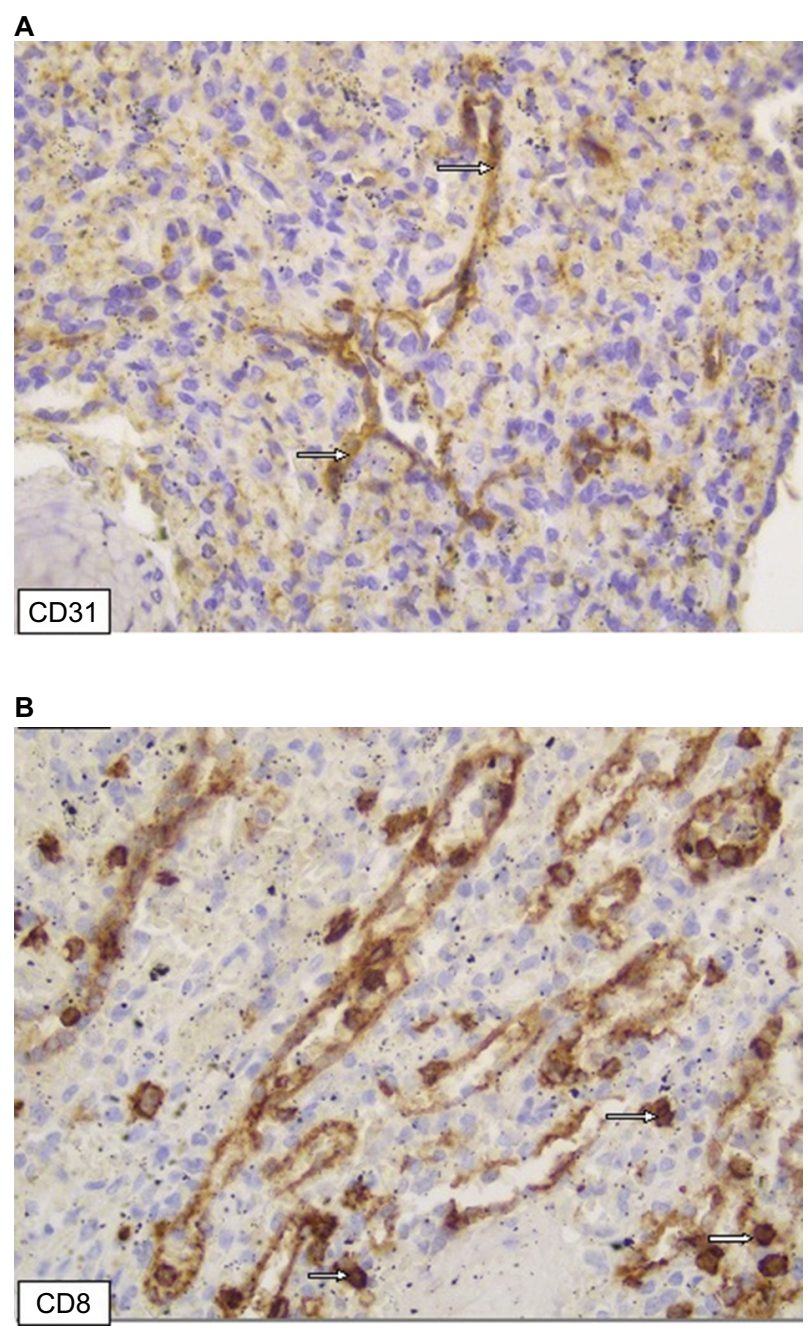

Figure 2 Endothelial cells are CD3 I- and CD8-positive.

Notes: (A) CD31, arrow indicates positive endothelial cells. (B) CD8, arrows indicate positive endothelial cells.

Abbreviation: $C D$, cluster of differentiation.

\section{Discussion}

Splenoma is a rare and benign tumor of the spleen. Its reported surgical incidence reaches three cases out of 200,000 splenectomies. Incidence ranges from $0.024 \%$ to $0.13 \%$ at autopsy. ${ }^{3,4}$ Hamartoma means "scribal error or mistake"; it is a tumor-like disorderly proliferation of cells and tissues indigenous to the site in which the hamartoma is located. The tumor-like expansion of the splenic parenchyma is due to the presence of heterologous fibroinflammatory, calcific and siderotic deposits. It seems that these lesions most likely result from remote ischemic or infectious/inflammatory and reparative injury to the spleen. Splenoma may be associated with tuberous sclerosis, Wiskott-Aldrich-like syndrome and hypersplenism (thrombocytopenia, anemia and pancytopenia). It has been shown that splenic hamartomas may arise from an acquired proliferative process. ${ }^{5}$ 

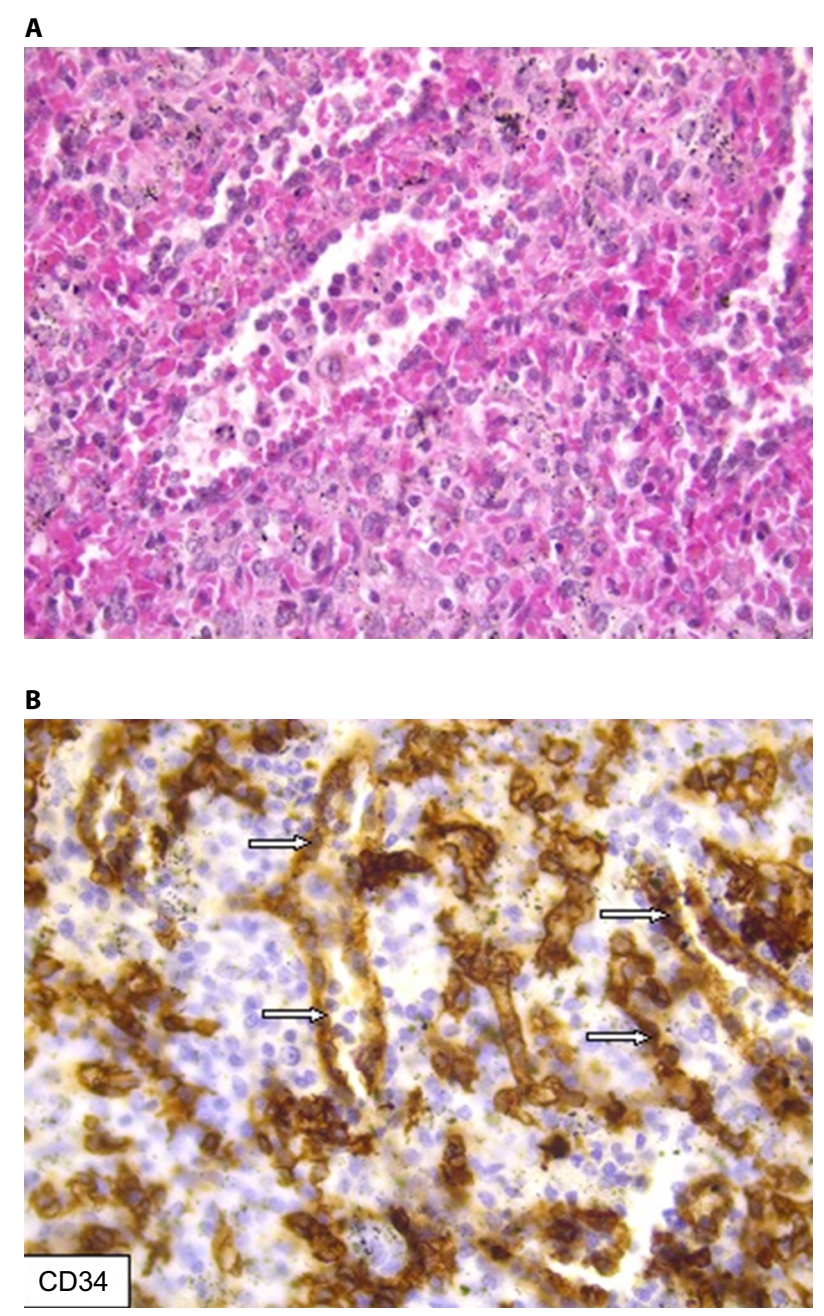

Figure 3 Vascular channels are CD34+.

Notes: (A) Capillary proliferation in microscopy; (B) CD34; arrows indicate positive endothelial cells.

Abbreviation: $C D$, cluster of differentiation.

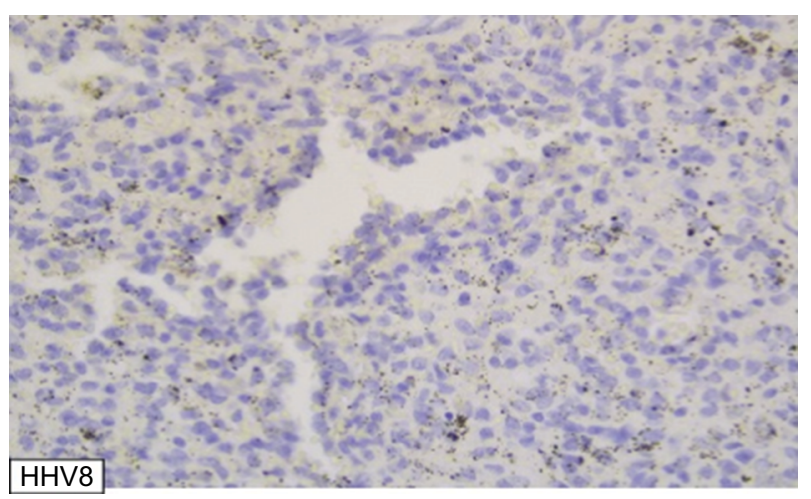

Figure 4 Vascular channels are HHV8-negative.

Abbreviation: HHV8, human herpesvirus 8.

Although most reported cases involve adult patients, some studies suggest that $20 \%$ of splenomas might actually be found in children. ${ }^{6-8}$ However, $<40$ cases have been reported in the literature. In $>50 \%$ of these cases, an association with hematological abnormality has been noted. ${ }^{9}$ Most patients are fully asymptomatic. Our patient underwent a total conventional splenectomy. Currently, laparoscopic splenectomy (LS) is the standard technique for the treatment of most benign and malignant splenic diseases. However, the spleen is a fragile organ, which can bleed when the capsule is injured. In order to prevent the risk of manipulation, in case of massive splenomegaly, open total or partial splenectomy was described with the advantage of easy control of hemorrhage. ${ }^{6,7}$

Although only histopathology provides the final diagnosis of splenoma, preoperative diagnosis using a combination of imaging techniques may be possible. As seen during ultrasonography, ${ }^{10}$ most splenic hamartomas present as hyperechoic masses with hypervascular signal during Doppler ultrasonography and angiography. The operator may notice cystic changes as seen on the ultrasonogram.

The results of tomodensitometry show average or lowdensity solid masses and demonstrate heterogeneous contrast enhancement as compared to surrounding tissues. ${ }^{11}$

Magnetic resonance imaging (MRI) is the most adequate technique to differentiate hamartomas from hemangiomas. Most lesions are isointense on T1 images. They are heterogeneously hyperintense on T2 images. On dynamic contrast-enhanced MRI sequences, it is typical to observe faint, heterogeneous enhancement on immediate postcontrast images. ${ }^{12}$ These are the key features in the differentiation between hamartomas and hemangiomas. On delayed postcontrast images, the splenoma is enhanced in a relatively uniform and intense fashion and may show central hypovascular areas.

During routine histological examination, splenomas can be easily differentiated from some neoplastic disorders, such as angiosarcoma, lymphoma and multiple splenic metastases. However, immunohistochemical staining is required to distinguish hemangiomas from splenomas.

Splenoma usually presents as a unique well-circumscribed nodule, ${ }^{2}$ but it sometimes has a multiple nodule presentation.

Histologically, it is an abnormal cluster of normal elements of the splenic red pulp, without any white pulp. It is made of a mixture of unorganized vascular channels lined by endothelial cells, surrounded by fibrotic cords.

On immunohistochemistry, splenic hemangiomas, similar to other hemangiomas, are vascular tumors whose endothelium does not express CD8. In contrast, splenomas contain splenic-type endothelial cells expressing CD8 antigen. ${ }^{13}$

Thus, clinical and radiological appearances of splenic hemangiomas and hamartomas overlap. MRI can identify the difference. The final diagnosis is provided by histopathology, especially immunohistochemistry. 


\section{Acknowledgment}

The authors thank Elise Martin, Antoine Defo and Sitraka Herinantenaina Razafindrakoto from Pediatric Medicine and Surgery, Cayenne Hospital, Cayenne Cedex, French Guiana, for data collection.

\section{Disclosure}

The authors report no conflicts of interest in this work.

\section{References}

1. Carlomagno N, Duraturo F, Candida M, et al. Multiple splenic hamartomas and familial adenomatous polyposis: a case report and review of the literature. J Med Case Rep. 2015;9:154.

2. Stanislas S, Parrens M. Atlas de pathologie splénique. Sauramps médical; Montpellier; 2009:141-161.

3. Zhang LF, Tou JF, Wang X, Gu WZ, Ma XH, Qin Q. Splenic hamartomas in two children. World J Surg Oncol. 2014;12:180.

4. Sim J, Ahn HI, Han H, et al. Splenic hamartoma: a case report and review of the literature. World J Clin Cases. 2013;1(7):217-219.

5. Abramowsky C, Alvarado C, Wyly JB, Ricketts R. "Hamartoma" of the spleen (splenoma) in children. Pediatr Dev Pathol. 2004;7(3): 231-236.
6. Ceretti AP, Bislenghi G, Virdis M, Maroni N, Gatti A, Opocher E. Laparoscopic splenectomy for splenic hamartoma: a case report. Case Rep Gastrointest Med. 2012;2012:435802.

7. Namikawa T, Kitagawa H, Iwabu J, Kobayashi M, Matsumoto M, Hanazaki K. Laparoscopic splenectomy for splenic hamartoma: case management and clinical consequences. World J Gastrointest Surg. 2010;2(4):147-152.

8. Hayes TC, Britton HA, Mewborne EB, Troyer DA, Saldivar VA, Ratner IA. Symptomatic splenic hamartoma: case report and literature review. Pediatrics. 1998;101(5):E10.

9. Benkirane A, Berrebi D, Olaya N, et al. Hamartome de la rate (splénome) chez un enfant drépanocytaire. [Hamartoma of the spleen (splenoma) in a child with sickle cell anemia]. Ann Pathol. 2007;27(1):27-30. French.

10. Kim HS, Kim TH, Lee JM, et al. [A case of splenic hamartoma diagnosed by contrast-enhanced ultrasonography and magnetic resonance imaging]. Korean J Gastroenterol. 2014;64(6):380-386.

11. Chou YH, Chiou HJ, Tiu CM, Chiou SY, Hsia CY, Tsay SH. Splenic hamartoma: presentation on contrast-enhanced sonography. J Clin Ultrasound. 2004;32(8):425-428.

12. Ramani M, Reinhold C, Semelka RC, et al. Splenic hemangiomas and hamartomas: MR imaging characteristics of 28 lesions. Radiology. 1997;202(1):166-172.

13. Zukerberg LR, Kaynor BL, Silverman ML, Harris NL. Splenic hamartoma and capillary hemangioma are distinct entities: immunohistochemical analysis of CD8 expression by endothelial cells. Hum Pathol. 1991;22(12):1258-1261.
International Medical Case Reports Journal

\section{Publish your work in this journal}

The International Medical Case Reports Journal is an international, peer-reviewed open-access journal publishing original case reports from all medical specialties. Previously unpublished medical posters are also accepted relating to any area of clinical or preclinical science. Submissions should not normally exceed 2,000 words or

\section{Dovepress}

4 published pages including figures, diagrams and references. The manuscript management system is completely online and includes a very quick and fair peer-review system, which is all easy to use. Visit http://www.dovepress.com/testimonials.php to read real quotes from published authors.

Submit your manuscript here: https://www.dovepress.com/international-medical-case-reports-journal-journal 